\title{
Peer Coaching and Mentoring in a Reflective Collaborative Community of Practice: A corpus- based analysis of blended MA TESOL teacher education programme
}

\author{
Nassima BOUKHARI \\ Teacher Professional Development and Reflective Practice, University of Limerick
}

\begin{abstract}
There is a plethora of models in the spectrum of continuing professional development that aim to collaborative endeavor and support teachers' autonomy, namely the peer coaching and mentoring model. Many studies, therefore, have examined the peer-networking, collaborative reflection, social interaction, and peer-support-group as a powerful catalyst to raise teachers' professional growth within a community of practice (Beatty 2000, Farrell 2014, Smith 1999). Language teachers should continually engage in CPD opportunities to reshape their existing skills and knowledge about teaching and learning (Farrell, 2007). This knowledge has been developed firstly in teacher professional development programmes and then has gradually become part of their education throughout their careers when they involve in reflective practice. Guskey's seminal work (2002) on teacher change through CPD proposes that there are three areas of impact, or 'change', that are expected as a result of teacher engagement in CPD: 'change in the classroom practices of teachers, in their attitudes and beliefs, and in the learning outcomes of students' (2002, p. 381). Kennedy (1997) states that it is not obvious what the source of those beliefs might be - an output of their education, a reflection of their life experiences, or an outcome of socialization procedures in schools. In this line, a teacher 's belief has more influence than teacher 's knowledge on deciding his or her teaching practices.
\end{abstract}

Recently, in the field of teacher education, there has been a focus on communities of learning. According to Wenger (1998a), communities of practice include a group of people with the same mutual interests and objectives wherein, they do communicate and interact to promote 


\section{3rd International Conference on}

New Trends in Teaching and Education

learning and find solutions to the identified problem with an innate belief that the group knowledge development is more beneficial than individual's benefit However, little research has been done into the use of online technologies for social networking and online community of practice. As a result, this research shines some lights on the reflective discourse of face to face and online community of student teachers and a peer mentor in a designed TESOL teacher education practicum.

This study has a multifaceted focus. Firstly, it tends to explore both novice and expert student teachers' current knowledge and experiences in reflective practice for teaching and learning. Then, it aims to investigate their beliefs and attitudes towards reflective practice, peer coaching, and blended modes of teacher education, i.e., whether they think that social interaction and reflective dialogue help their professional growth. In addition, the main purpose of this work is to examine the characteristics and the evidence of the dialogic discourse in face to face and computer mediated modes of communication, as well as, to extrapolate the maintenance of a community of learning through interaction and dialogue between the peer tutor and the student teachers and peer scaffolding between novice and expert teachers. Finally, this research further attempts to find out student teachers' post-course perceptions towards the use of blended interactions and dialogic reflection.

The rationale of this study is to design and assess a CPD action research intervention for four cohorts of MA TESOL student teachers at the University of Limerick, Ireland. This research is methodologically innovative in the ways it seeks to examine and study physical and computer-mediated discussions through quantitative and qualitative corpus-based analysis after recorded face to face workshops, "Microsoft Teams" online tutoring sessions, and chatroom discussions. Moreover, the MA TESOL student teachers' current knowledge, beliefs, attitudes and perceptions towards reflective practice, peer interaction, and blended mode course will be provided through a need's analysis questionnaire at the beginning, and a post-course questionnaire and an interview to have valid findings. 


\section{3rd International Conference on}

New Trends in Teaching and Education

09-11 JULY 2021

Paris, France

Key words: Teacher education, Continuing Professional Development, Reflective Practice, Peer collaboration, Coaching and mentoring, Community of practice, Computer-assisted learning, Beliefs and Attitudes.

\section{References:}

-Beatty, B.R. (2000) Teachers Leading their Own Professional Growth: self-directed reflection and collaboration and changes in perception of self and work in secondary school teachers, Journal of In-Service Education, 26, pp. 73-91.

- Farrell, T. S. C. (2007). Reflective language teaching: From research to practice. London, England: Continuum.

- Farrell, T. S. C. (2014). Reflective practice in ESL teacher development groups: From practices to principles. Basingstoke, England: Palgrave Macmillan

- Guskey, T., 2002. 'Professional development and teacher change'. Teachers and teaching: theory and practice, 8 (3/4), 381-391.

- Kennedy, Mary M. (1997). Defining an ideal teacher education program [mimeo]. Washington, DC: National Council for the Accreditation of Teacher Education. 1-29.

- Smith, P.V. (1999) Managing Continuing Professional Development to Support Schoolbased Target Setting, Journal of In-Service Education, 25, pp. 85-95.

- Wenger, E. (1998a) Communities of Practice. Learning, Meaning, and Identity, Cambridge: Cambridge University Press 